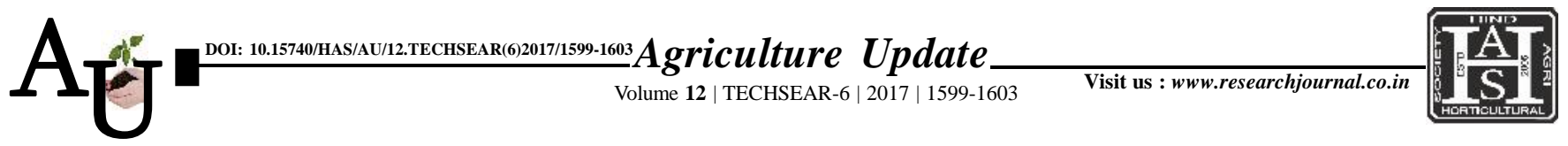

\title{
Research Article: Socio-economic factors influencing the different paddy residue management practices TBP command area in Karnataka
}

\author{
SANGMESH CHENDRASHEKHAR, G. B. LOKESH, SURESH S. PATIL AND \\ H. LOKESHA
}

Article Chronicle :

SUMMARY : In Tunga Bhadra Project (TBP) command area of Karnataka, paddy-paddy cropping Received :

17.07.2017;

Accepted :

01.08.2017

KeY WoRDS :

Residue, Burning, Incorporation, Management

Author for correspondence : system is the predominant higher system. Paddy residues include any biomass left in the field after grains and other economic components have been harvested. In High Livestock Density Area (HLDA) average age of respondents was 43.34 years, among different practices of paddy residue burning of straw and stubbles is having average age of respondent is 45.89 years, followed by removal straw and burning of stubbles (43.2), incorporation of straw and stubbles (42.83) and removal of straw and incorporation stubbles (41.30). Whereas, in Low Livestock Density Area (LLDA) average age of respondent was 42.17 years, among different practices incorporation of straw and stubbles is having average age of respondent was 47.20 years, followed by burning of straw and stubbles (43.08), removal of straw and burning stubbles (40.68) and removal of straw and incorporation stubbles (37.70) years. Constraints analysis indicated that, among availability of short time between Kharif paddy harvesting and sowing of Rabi paddy was identified as major constraints and it stands Rank- I (71.54 mean Garret score ) followed by scarcity of labour for residue collection after use of combine harvesters Rank - II (60.70) in High Livestock Density Area (HLDA) whereas, in case of Low Livestock Density Area (LLDA), among this availability of short time between Kharif paddy harvesting (late October and early November) and sowing of Rabi paddy was identified as major constraints and it stands Rank- I (73.22 mean Garret score ) followed by high cost of residue management compared to burning Rank - II (56.70).

How to cite this article : Chendrashekhar, Sangmesh, Lokesh, G. B., Patil, Suresh S. and Lokesha, H. (2017). Socio-economic factors influencing the different paddy residue management practices TBP command area in Karnataka. Agric. Update, 12(TECHSEAR-6) : 1599-1603; DOI: 10.15740/HAS/AU/12. TECHSEAR(6)2017/ 1599-1603.

\section{SANGMESH}

CHENDRASHEKHAR

Department of

Agricultural Economics, University of Agricultural Sciences, RAICHUR (KARNATAKA) INDIA

Email: sangmeshrampure @ gmail.com 